\title{
A revaluation of all values
}

George Steiner

Science in a Free Society. By P. Feyerabend. Pp. 221. (New Left Books: London, 1978.) $£ 7.50$.

Formally, this book is a mess. It is a patchwork of polemic, of autobiographical fragments, of re-iterations of or rapid addenda to an earlier book, Against Method: Outline of an Anarchistic Theory of Knowledge (New Left Books: London, 1978). In fact, it will make almost no sense to anyone who has not read Paul Feyerabend's main tract or who has not kept its principal arguments and areas of reference clearly in mind. The tone is, once again, truculent, selfserving, caustically dismissive of dissent and, at pivotal moments, rhetorical. A paragraph, chosen almost at random, will communicate the flavour and purpose (one can choose almost at random precisely because the technique of argument is one of circular incantation):

\begin{abstract}
"Of course, our well conditioned materialistic contemporaries are liable to burst with excitement over events such as the moonshots, the double helix, non-equilibrium thermodynamics. But let us look at the matter from a different point of view, and it becomes a ridictilous exercise in futility. It needed billions of dollars, thousands of well-trained assistants, years of hard work to enable some inarticulate and rather limited contemporaries to perform a few graceless hops in a place nobody in his right mind would think of visiting-a dried out, airless, hot stone. But mystics, using only their minds travelled across the celestial spheres to God himself whom they viewed in all his splendour receiving strength for continuing their lives and enlightenment for themselves and their fellow men. It is only the illiteracy of the general public and of their stern trainers, the intellectuals, and their amazing lack of imagination that makes them reject such comparisons without further ado."
\end{abstract}

The sleight-of-hand whereby moonshots, work on DNA and the mathematics and/or technology of non-equilibrium thermodynamics are conflated is no less representative of Professor Feyerabend's method than is the bullying lack of punctuation throughout the latter part of the passage.

As readers of Against Method will know, the author has two principal and related aims: to demystify the alleged rationality and methodological integrity of the 'exact' sciences and to remove these sciences from the prestigious, politically and socially determinant rôle which they play in current western society. To borrow Nietzsche's tag, Professor

\section{Sorry, for copyright reasons some images on this page may not be available online}

Feyerabend is arguing for 'a revaluation of all values':

\begin{abstract}
"Bringing a faint smile to the faces of people who have been hurt, disappointed, depressed, who arc paralysed by some 'truth' or by the fear of death seems to me an achievement infinitely more important than the most sublime intellectual discovery: Nestroy, George S. Kaufman, Aristophanes, on my scale of values range far above Kant, Einstein and their anaemic imitators."
\end{abstract}

Feyerabend's position might be defined as that of a 'therapeutic anarchist' (it is very close to that of an educational iconoclast such as Ilich, who figures in the text if not in the index). The enemy, among others, is Popper: Sir Karl is "a mere propagandist" whose teachings and following constitute "a tiny outhouse" (elegance of expression is not among Professor Feyerabend's weaknesses). But the fundamental enemyand here Feyerabend's polemic is precisely on target-is "the rise of intellectualism in Ancient Greece", and the unfolding of this intellectualism in the methodologies of Descartes and Kant and in the scientific world-image of Newton and his modern inheritoss. It is this intellectuaiism', this belief ('illusory, naïve, finally ludicrous, says Feyerabend) in 'objective truths' and in the disinterested passions of abstract, mathematically-grounded theorising, which have brought the west to its current state of confused inhumanity. Trapped in our naïve, wasteful 'scientism', we no longer even have access to the pluralistic possibilities inherent in the 'animism', in the 'mysticism', in the intuitive, mythologically articulate mentalities and wealth of humane insight in cultures, in modes of apprehension which we have ostracised as 'primitive' or 'irrational' (as if the actual procecdings which led to the Copernican revolution or to Einsteinian relativity were not, in their own way, 'primitive' and 'irrational').

The text is most rewarding where it tells of the personal and pedagogic road which led Paul Feyerabend to his current

$\breve{s}$ stance. Kierkegaard's anti-rationalism was an incitement. Dada and the expressionist send-ups immediately after World War I were important (Feyerabend is Eabsolutely right when he notes that E Dadaists went deeper than anyone else

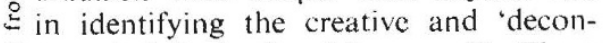
5 structive" "miracle of language"). There were Austrian Marxism and the Vienna School, with its ultimately unfulfilled promise of a rigorous yet also accurately descriptive logic of the sciences. And, above all, perhaps, there was California, with its plethora of informalities, instant utopias, 'Orientalisms', 'counter-cultures" and liberating sunshine.

If Feycrabend often knocks down straw-men - who now refuses to argue the status of the exact sciences, what serious mind is not worrice about the technocratic enormities in our environment and politics?- he also scores shrewd hits. He is acute on the innocent 'scientism' of the Vienna Circle; his critique of positivistic paradigms amends and deepens Kuhn. He is robustly antiparochial, following Protagoras in the conviction that a pluralistic view of values and ideals is the only way of stepping beyond one's village towards the human community at large. Thus, Professor Feyerabend's plea for a new catholicity of understanding is often poignant and persuasive. It is also, now and again, great fun. That a more patient sensibility, that a style of inquiry less contemptuous of disagreement, would give to Against Method a more effective place in the present climate of discourse, are considerations which, one fears, Paul Feyerabend would regard as time-serving, silly or both. The dust-jacket photo of the faintly sneering author seems to declare as much. This is a pity, for the issues raised are of the first importance.

George Steiner is Professor of English and Comparative Literature at the University of Geneva, Switzerland. 